\title{
Assessment of renal function in workers previously exposed to cadmium
}

\author{
CG ELINDER, ${ }^{1} \mathrm{C}$ EDLING,${ }^{2}$ E LINDBERG,${ }^{1}$ B KÅGEDAL,${ }^{3}$ AND O VESTERBERG \\ From the Department of Occupational Medicine, ${ }^{1}$ Research Department, National Board of Occupational \\ Safety and Health, S-171 84 Solna, Department of Occupational Medicine, ${ }^{2}$ University Hospital, and \\ Department of Clinical Chemistry, ${ }^{3}$ University of Linköping, S-581 85 Linköping, and Chemistry Division, ${ }^{4}$ \\ Research Department, National Board of Occupational Safety and Health, S-171 84 Solna, Sweden
}

ABSTRACT Cadmium induced renal effects were examined in 60 workers (58 men, 2 women) previously exposed to cadmium. Tubular damage in the form of $\beta_{2}$-microglobulinuria was found in $40 \%$, and urinary albumin and orosomucoid increased significantly with increasing urinary cadmium and increasing relative clearance of $\beta_{2}$-microglobulin. It is suggested that increased albumin excretion is secondary to the tubular damage. In no case was typical glomerular proteinuria found that could be related to cadmium. Histories of renal stones were more common among the workers with high urinary cadmium concentrations. The glomerular filtration rate was measured in 17 of the workers who had pronounced tubular dysfunction. The average glomerular filtration rate for these men was less than the age adjusted predicted value $(\overline{\mathrm{x}}=84 \%)$. Furthermore, there was a significant $(p<0.05)$ correlation $(r=-0.47)$ between tubular reabsorption loss and a decreased glomerular filtration rate.

Cadmium is well known as a nephrotoxic agent ${ }^{12}$ and several groups of investigators have described the urinary findings in cadmium workers. ${ }^{13-11}$ The most typical finding is an increased urinary excretion of low molecular weight serum proteins such as $\beta_{2}$-microglobulin, whereas the excretion of larger proteins, such as albumin, increases much less. ${ }^{1213}$ This is evidence of tubular damage or dysfunction. ${ }^{1214-16}$ The cadmium induced tubular dysfunction may also lead to an increased urinary excretion of other substances that are filtered through the glomerulus and normally reabsorbed in the tubular cells-for example, glucose, aminoacids, and calcium. $^{217}$ An increased prevalence of renal stones among cadmium workers has been reported from Sweden ${ }^{18}$ and from the United Kingdom, ${ }^{1921}$ but not from other countries. ${ }^{2}$

Bernard and his co-workers found that some cadmium workers also have an increased urinary excretion of larger proteins; albumin, transferrin, and IgG, and based on this observation suggested that cadmium may also induce a glomerular type of proteinuria. $^{1011}$

Received 18 February 1985

Accepted 25 March 1985
In severe cases of renal cadmium poisoning glomerular filtration may also be impaired. Friberg found that the average inulin clearance was lowered among workers who had cadmium induced proteinuria ${ }^{1}$ and Adams et al reported that most of the men with cadmium induced proteinuria also had decreased creatinine clearance rates. ${ }^{19}$ In a few cases the cadmium induced renal damage eventually led to uraemia and death. 2223

The objecive of the present study was to provide additional information on the nature of the cadmium induced renal effects. Is there a higher prevalence of renal stone disease? Is there evidence for the glomerular and the tubular type of proteinuria? What is the significance of a raised urinary $\beta_{2}$-microglobulin concentration? Is there any relation between tubular damage and a decrease in the glomerular filtration rate (GFR)?

\section{Subjects}

Sixty eight workers who had been exposed for at least five years before 1978 in a factory using cadmium containing solders were invited to take part in a health examination. Six refused and two had died. The remaining 60 (58 men aged 27-78 and 2 women 
aged 29-30) took part. The mean age at the time of the health examination was 48 .

\section{Exposure}

The factory which produces coolers, radiators, and heat exchangers used cadmium containing solders between 1955 and 1978. The whole production hall was heavily contaminated with cadmium, and measurements carried out in 1976 showed atmospheric cadmium concentrations ranging from 0.01 to 2 $\mathrm{mg} / \mathrm{m}^{3}{ }^{24}$ During 1977 and 1978 the environmental conditions were improved, but it was not until the middle of 1978 , when cadmium solders were abandoned, that exposure to cadmium ceased completely. Further data about the exposure as well as dose response analyses will be published elsewhere.

\section{Health examination}

Each participant was asked to answer a self administered questionnaire that included questions about present and previous diseases, history of renal stones, use of drugs, and smoking habits. The answers given in the questionnaire were compared with those of a reference group of 127 industrially employed men working in the same district but not occupationally exposed to cadmium. The mean age of the reference group was 38 .

In acidic urine $(\mathrm{pH}<5.6) \beta_{2}$-microglobulin may be degraded. ${ }^{25}$ To prevent this, each person ingested about $4 \mathrm{~g}$ of sodium bicarbonate (Samarin) the night before morning urine was collected for protein analyses.

Urine was sampled in carefully washed polyethylene bottles with a small addition (about $10 \mathrm{mg}$ ) of sodium azide to prevent bacterial growth. Venous blood samples were taken in $10 \mathrm{ml}$ evacuated test tubes without additives. Serum was obtained after coagulation and centrifugation. Serum and urine samples were kept at a temperature close to $0^{\circ} \mathrm{C}$ until frozen. The physical examination included measurement of systolic and diastolic blood pressure in the left arm with the patient in the horizontal position. The lung function, as measured by spirometry and single breath nitrogen washout, will be presented elsewhere.

\section{Methods}

All chemical analyses were carried out at the Chemical Division, National Board of Occupational Safety and Health. Albumin, $\beta_{2}$-microglobulin, orosomucoid, and creatinine were determined in serum and urine. Cadmium, specific gravity, and $\mathrm{pH}$ were also determined in urine. In addition, all urine sam- ples were screened for the occurrence of glucose, red blood cells, and bacteria, using indicator paper. Albumin and orosomucoid were measured by zone immunoelectrophoresis ${ }^{26}$ and $\beta_{2}$-microglobulin by a radio immunoassay (Phadebas, Pharmacia, Sweden). Creatinine was determined using a colorimetric method and a reaction rate analyser, LKB $8600 .^{27}$ Cadmium in urine was measured by atomic absorption spectrophotometry using electrothermal atomisation. ${ }^{28}$ The urinary excretion of cadmium and proteins was related to the urinary excretion of creatinine, and reported as $\mathrm{mg}$ or $\mathrm{nmol} / \mathrm{mmol}$ of creatinine.

The relative clearance of $\beta_{2}$-microglobulin was estimated according to the formula ${ }^{29}$

$\frac{\mathrm{Cl} \beta_{2}}{\text { Clcreatinine }}(\%)=100 \times \frac{\mathrm{U}-\beta_{2} \times \mathrm{S} \text {-creatinine }}{\mathrm{S}-\beta_{2} \times \mathrm{U} \text {-creatinine }}$.

The GFR was measured in 17 men who had raised urinary $\beta_{2}$-microglobulin excretion exceeding $0.06 \mathrm{mg}$ $\beta_{2} / \mathrm{mmol}$ creatinine at the Department of Clinical Chemistry in Linköping, using a CrEDTA plasma clearance technique as described by BröchnerMortensen. ${ }^{30}$

Data on urinary albumin excretion from one person $(35.8 \mathrm{mg} / \mathrm{mmol}$ creatinine) were excluded. This 63 year old man had been diagnosed in 1982 as having an interstitial nephritis or nephrosclerosis of unknown aetiology. His glomerular filtration rate was found to be reduced, $53 \mathrm{ml} / \mathrm{min}$, and he had obtained a sickness pension. In view of his comparably low urinary excretion of cadmium $(5 \mathrm{nmol} / \mathrm{mmol}$ creatinine) and normal urinary excretion of $\beta_{2}$-microglobulin he probably suffers from a renal disease not primarily related to, or caused by, occupational exposure to cadmium.

\section{Normal values}

The normal urinary excretion of cadmium, albumin, and $\beta_{2}$-microglobulin has been well documented. The upper 95 or 97.5 percentile for normal urinary cadmium, albumin, and $\beta_{2}$-microglobulin excretion is about $2 \mathrm{nmol} \mathrm{Cd} / \mathrm{mmol}$ creatinine, ${ }^{31} 1.5 \mathrm{mg}$ albumin/mmol creatinine 263233 and $0.034 \mathrm{mg}$ $\beta_{2}$-microglobulin/mmol creatinine. ${ }^{3234}$ The normal urinary excretion of orosomucoid in one report ranged up to about $0.5 \mathrm{mg} / \mathrm{mmol}$ creatinine. ${ }^{32}$

Another group of industrial workers $(n=32)$ not exposed to cadmium was examined shortly after the exposed group in this study. Using the same methods and techniques as for the cadmium exposed group, the urinary cadmium excretion was found to be less than $1.0 \mathrm{nmol} / \mathrm{mmol}$ creatinine. The median protein concentrations were: $0.4 \mathrm{mg}$ albumin $/ \mathrm{mmol}$ creatinine (range $0 \cdot 1-8.4$ ), $0.02 \mathrm{mg}$ orosomucoid $/ \mathrm{mmol}$ 
creatinine (range $<0.003-0.28$ ), and $0.004 \mathrm{mg}$ $\beta_{2}$-microglobulin $/ \mathrm{mmol}$ creatinine (range $0.002-$ $0 \cdot 020$ ).

Normally, about $99.96 \%$ of the filtered amount of $\beta_{2}$-microglobulin is absorbed in the tubules and thus the urinary excretion is about $0.04 \% .{ }^{1529}$ If, for example, the $\beta_{2}$-microglobulin clearance is $10 \%$ of the creatinine clearance this may be regarded as a $10 \%$ decrease in the normal tubular reabsorption of $\beta_{2}$-microglobulin.

CrEDTA clearance was corrected to a body surface area of $1.73 \mathrm{~m}^{2}$ based on the height and body weight of the person examined. As GFR decreases with age a ratio was calculated between the observed and predicted GFR according to the age of the subject. Age related changes in GFR when determined by the CrEDTA technique used in the present study have been reported by Granerus and Aurell. ${ }^{35}$

\section{Results}

The completed questionnaires showed no significant differences between the exposed and control groups with regard to subjective complaints of ill health, kidney stones, or other diseases of the kidney. Eight $(14 \%)$ of the exposed men had a history of kidney stone (stones) compared with $12(9 \%)$ of the controls $(p>0 \cdot 10)$. Within the exposed group a history of renal stones was, however, significantly $(p=0.025$ using one tailed exact probability test) more common among those who had had urinary cadmium excretion exceeding the median value for the whole group $(6.3 \mathrm{nmol} / \mathrm{mmol}$ creatinine) compared with those who excreted less cadmium (table 1). Furthermore, four of the eight men with renal stones had urinary $\beta_{2}$-microglobulin concentrations exceeding $0 \cdot 1$ $\mathrm{mg} / \mathrm{mmol}$ creatinine. Only 10 of the remaining 50 men without renal stones had urinary $\beta_{2}$-microglobulin excretion exceeding the concentration $\left(\mathrm{chi}^{2}=3.39\right.$ without Yates's correction, $\mathrm{p}=\mathbf{0 . 0 7}$ two tailed).

Twenty four $(40 \%)$ of the exposed workers had urinary $\beta_{2}$-microglobulin concentrations exceeding $0.034 \mathrm{mg} / \mathrm{mmol}$ creatinine and $14(23 \%)$ had urinary $\beta_{2}$-microglobulin concentrations exceeding $0 \cdot 1$ $\mathrm{mg} / \mathrm{mmol}$ creatinine. The prevalence of proteinuria increased with increasing urinary cadmium (table 2 ).
The increase was more pronounced for $\beta_{2}$-microglobulin and orosomucoid than for albumin. At urinary cadmium concentrations exceeding 10 $\mathrm{nmol} / \mathrm{mmol}$ creatinine the prevalence of raised $\beta_{2}$-microglobulin, orosomucoid, and albumin was $88 \%, 88 \%$, and $31 \%$ respectively.

The urinary excretion of $\beta_{2}$-microglobulin, orosomucoid, and albumin correlated significantly $(\mathrm{p}<0.05$ ) with cadmium (figs 1,2 , and 3 ). It may be seen in figs 1 and 2 that there is no real linear relation between urine cadmium and $\beta_{2}$-microglobulin or orosomucoid. In these figures we have therefore also included lines that describe the "floating average" of urine proteins $\left(\beta_{2}\right.$-microglobulin and orosomucoid) for the nearest five urine cadmium data, that is

$$
y_{x_{1-2}}-x_{i+2}=\left(y_{x_{1-2}}+y_{x_{i-1}}+\ldots y_{x_{i+2}}\right): 5 \text {. }
$$

For urinary $\beta_{2}$-microglobulin there appears to be a threshold around $9 \mathrm{nmol} \mathrm{Cd} / \mathrm{mmol}$ creatinine. Above this concentration the average $\beta_{2}$-microglobulin increases appreciably.

Urinary albumin (fig 3) increases only slightly, but still correlates significantly, with increasing urinary cadmium. The slope constant is, however, considerably lower than those for $\beta_{2}$-microglobulin and orosomucoid.

Urinary orosomucoid and albumin excretion have been depicted in figs 4 and 5 as a function of increasing relative $\beta_{2}$-microglobulin clearance

$$
\left(\frac{\mathrm{Cl} \beta_{2}}{\text { Clcreatinine }} \%\right)
$$

The urinary excretion of both proteins increases, but not to the same extent. The relative increase in orosomucoid (fig 4) is more pronounced than that for albumin (fig 5).

The GFR was measured in 17 of the workers and the values ranged from 41 to $127 \mathrm{ml} / \mathrm{min} / \mathrm{m}^{2}$ body surface. For each individual the ratio between observed GFR and the age and sex predicted GFR was estimated. The ratio varied between $57 \%$ and $127 \%$ with an overall average of $84 \%(\mathrm{SD}=18.4)$. This is significantly less $(p<0.05)$ than $100 \%$. In fig 6 the ratio between observed and predicted GFR has been related to the relative clearance of $\beta_{2}$-microglobulin. A weak but significant $(\mathrm{p}<0.05)$ negative linear or rank correlation was found; obs

Table 1 Number of exposed men with a history of renal stones, in relation to urinary cadmium

\begin{tabular}{lcccc}
\hline & $U-C d \leqslant 6 \cdot 3$ (nmol/mmol creatinine) & $U-C d>6 \cdot 3$ (nmol/mmol creatinine) & All \\
\hline History of renal stone(s) & 1 & 7 & 8 \\
No history of renal stone(s) & 28 & 22 & 50 & 58 \\
All & 29 & 29 & 5 \\
\hline
\end{tabular}

$\mathrm{Chi}^{2}=5 \cdot 19$ without Yates's correction.

$\mathrm{p}=0.025$ using one sided exact probability test. 
Table 2 Prevalence of $\beta_{2}$-microglobulinuria, orosomucoiduria, and albuminuria in relation to urinary cadmium

\begin{tabular}{|c|c|c|c|}
\hline$U-C d\left(\right.$ nmol/mmol creatinine $\left.{ }^{*}\right)$ & $\begin{array}{l}U-\beta_{2}>0.034(\mathrm{mg} / \mathrm{mmol} \\
\text { creatinine } \dagger)\end{array}$ & $\begin{array}{l}U \text {-orosomucoid }>0.5(\mathrm{mg} / \mathrm{mmol} \\
\text { creatinine } \ddagger)\end{array}$ & $\begin{array}{l}\text { U-albumin }>1.5(\mathrm{mg} / \mathrm{mmol} \\
\text { creatinine })\end{array}$ \\
\hline $\begin{array}{l}\leqslant 2 \\
2-\leqslant 5 \\
5-\leqslant 10 \\
10-\leqslant 15 \\
>15 \\
\text { All }\end{array}$ & $\begin{array}{c}1 / 14(7 \%) \\
3 / 12(25 \%) \\
6 / 18(33 \%) \\
4 / 5(80 \%) \\
10 / 11(91 \%) \\
24 / 60(40 \%)\end{array}$ & $\begin{array}{c}1 / 14(7 \%) \\
0 / 12(0 \%) \\
4 / 18(22 \%) \\
4 / 5(80 \%) \\
10 / 11(91 \%) \\
19 / 60(32 \%)\end{array}$ & $\begin{array}{l}2 / 14(14 \%) \\
1 / 12(8 \%) \\
1 / 17(6 \%) \\
1 / 5(20 \%) \\
4 / 11(36 \%) \\
9 / 59(15 \%)\end{array}$ \\
\hline
\end{tabular}

$* 1 \mathrm{nmol} \mathrm{Cd} / \mathrm{mmol}$ creatinine $=1 \mathrm{ug} \mathrm{Cd} / \mathrm{g}$ creatinine.

$+0.034 \mathrm{mg} \beta_{2} / \mathrm{mmol}$ creatinine $=0.3 \mathrm{mg} / \mathrm{g}$ creatinine

$+0.5 \mathrm{mg}$ orosomucoid $/ \mathrm{mmol}$ creatinine $=4.4 \mathrm{mg} / \mathrm{g}$ creatinine.

$\S 1.5 \mathrm{mg}$ albumin $/ \mathrm{mmol}$ creatinine $=13.2 \mathrm{mg} / \mathrm{g}$ creatinine.

GFR/pred GFR $(\%)=90 \%-1 \cdot 1 \times \frac{\mathrm{Cl} \beta_{2}}{\mathrm{Cl} \text { creat }}(\%)$.

The slope remained essentially unchanged even when the subjects with the most severe tubular impairment were excluded from the calculation $(a=90, b=1 \cdot 2)$ but the correlation is no longer significant.

\section{Discussion}

This study confirms that occupational exposure to cadmium may cause renal impairment, and that the first sign is an increased urinary excretion of low molecular weight proteins such as $\beta_{2}$-microglobulin and orosomucoid (figs 1 and 2 ). A relation was found between urinary cadmium and albumin (fig 3), similar to that previously reported for cadmium exposed workers in Belgium. ${ }^{1132}$

A history of renal stones was more common in the exposed group than in the reference group, although this did not attain statistical significance. The refer-

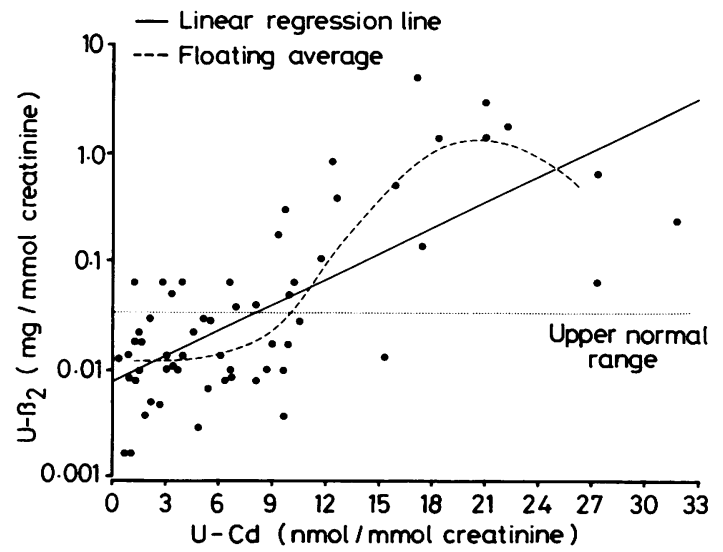

Fig 1 Urinary excretion of $\beta_{2}$-microglobulin in relation to urinary excretion of cadmium. Linear regression line; ${ }^{10} \mathrm{log}$ $U-\beta_{2}(\mathrm{mg} / \mathrm{mmol}$ creatinine $)=0.008+0.080 \times U-C d$ (nmol/mmol creatinine). ence group was, however, younger than the exposed group, and as the prevalence of renal stones increases with age ${ }^{36}$ this difference may be artificial. On the other hand, several workers in the exposed group had relatively low urinary cadmium concentrations and were thus not at the same risk of developing cadmium induced renal effects. Within the exposed group $(n=58)$ men with a history of renal stones had a significantly higher urinary cadmium concentration (table 1) and tended to have a higher urinary $\beta_{2}$-microglobulin excretion compared with those who had no history of stones. The mean age of the men with stones $(\overline{\mathrm{x}}=49)$ was similar to that of the whole group $(\bar{x}=48)$. Thus the present results give some support to the earlier findings of an increased frequency of renal stones in cadmium workers. ${ }^{18-21}$

Table 2 presents the prevalence rates for raised urinary $\beta_{2}$-microglobulin, orosomucoid, and albumin in relation to urinary cadmium. As no large control group was examined in parallel with the exposed

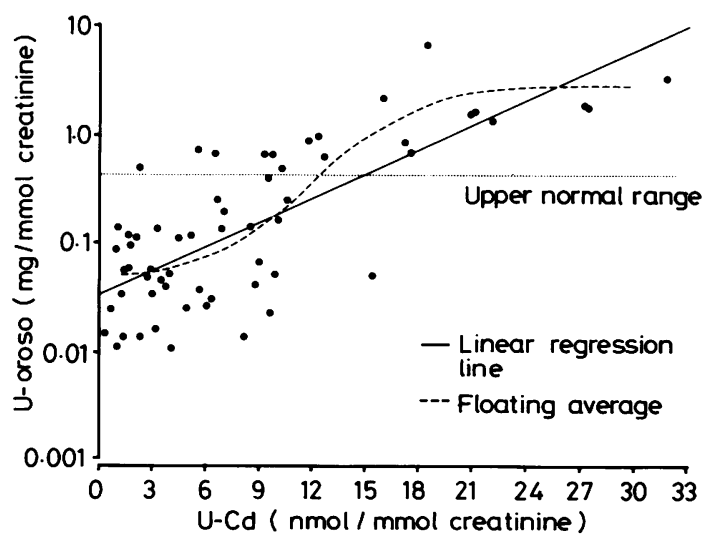

Fig 2 Urinary excretion of orosomucoid in relation to urinary excretion of cadmium. Linear regression line; ${ }^{10} \mathrm{log}$ $U$-orosomucoid $(\mathrm{mg} / \mathrm{mmol}$ creatinine $)=0.033+0.076 \times$ U-Cd ( nmol/mmol creatinine). 


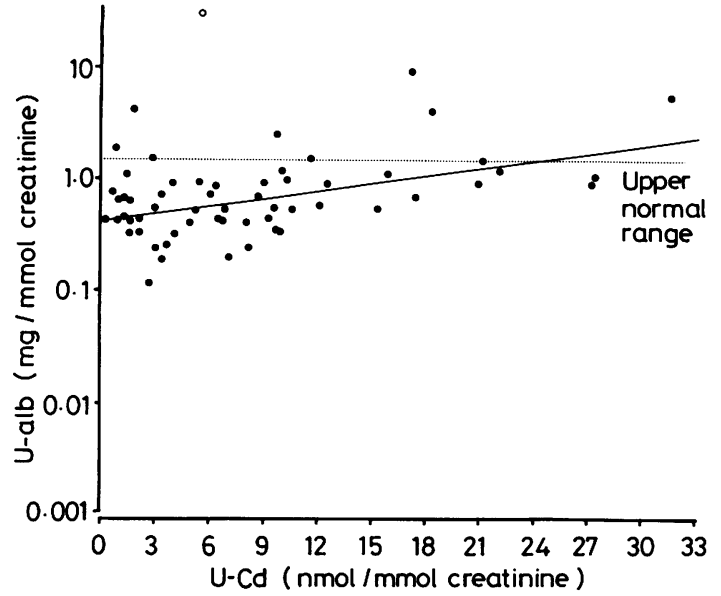

Fig 3 Urinary excretion of albumin in relation to urinary excretion of cadmium. Linear regression line; ${ }^{10} \mathrm{log}$ $U$-albumin ( $\mathrm{mg} / \mathrm{mmol}$ creatinine) $=0.43+0.023 \times U-C d$ (nmol/mmol creatinine). Unfilled dot depicts data from one excluded person (see methods).

group the upper normal ranges for the proteins in urine were derived from published data. ${ }^{2632-34}$ If other cut off levels are chosen the prevalence data will obviously be somewhat different, but as may be deduced from figs 1,2 , and 3 , the general appearance of the data will be similar to those in table 2 . If, for example, the cut off points for raised urinary

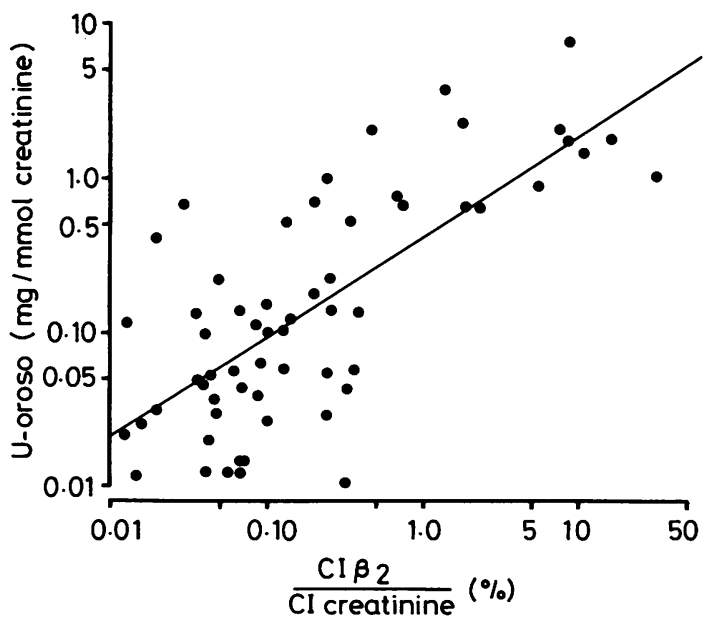

Fig 4 Urinary excretion of orosomucoid in relation to relative clearance of $\beta_{2}$-microglobulin. Linear regression line; ${ }^{10} \mathrm{log}$ orosomucoid ( $\mathrm{mg} / \mathrm{mmol}$ creatinine)

$=0.41+0.65 \times{ }^{10} \log \left(\frac{C l \beta_{2}}{\text { Clcreat }} \%\right)$.

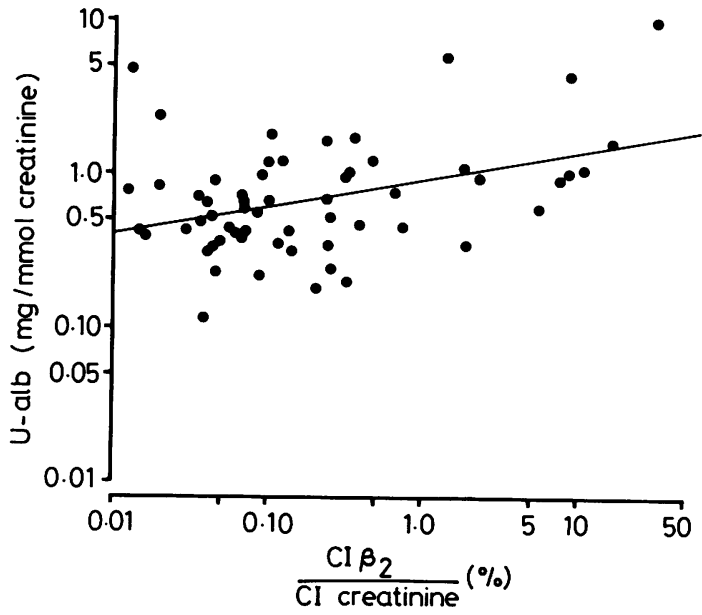

Fig 5 Urinary excretion of albumin in relation to relative clearance of $\beta_{2}$-microglobulin. Linear regression line; ${ }^{10} \mathrm{log}$ albumin $(\mathrm{mg} / \mathrm{mmol}$ creatinine $)=0.91+0.17 \times{ }^{10} \mathrm{log}$

$$
\left(\frac{\mathrm{Cl} \beta_{2}}{\text { Clcreat }} \%\right) \text {. }
$$

$\beta_{2}$-microglobulin, orosomucoid, and albumin were set at $0 \cdot 1,1$, and $2 \mathrm{mg} / \mathrm{mmol}$ creatinine, respectively, the prevalence figures would become; $0 / 14,0 / 12,2 / 18$, $3 / 5$, and $9 / 11$ for $\beta_{2}$-microglobulinuria, $0 / 14,0 / 12$, $0 / 18,1 / 5$, and $9 / 11$ for orosomucoiduria, and $1 / 14$ $0 / 12,1 / 17,0 / 5$, and $3 / 11$ for albuminuria.

All the urinary proteins studied correlated

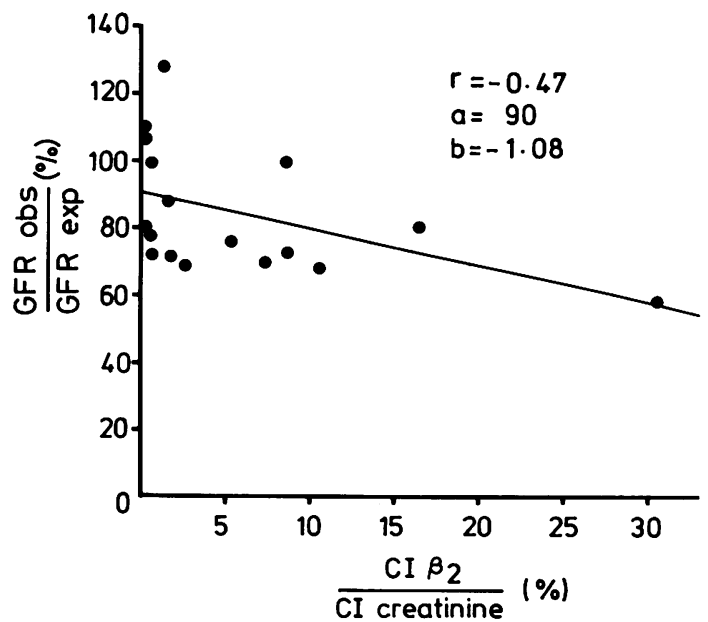

Fig 6 Ratio (\%) between observed and predicted glomerular filtration rate (GFR) by 17 men in relation to relative clearance of $\beta_{2}$-microglobulin. Linear regression line; $\frac{\text { Obs } G F R}{\text { Pred } G F R}(\%)=90-1.08 \times\left(\frac{C l \beta_{2}}{\text { Clcreat }} \%\right), r=0.47$. 
significantly with urinary cadmium. The increase was much clearer for $\beta_{2}$-microglobulin (fig 1) and orosomucoid (fig 2) than for albumin (fig 3), however. In figs 4 and 5 the urinary excretion of orosomucoid and albumin have been related to the relative clearance of $\beta_{2}$-microglobulin. Both urine orosomucoid and albumin increase significantly with decreasing tubular reabsorption capacity. For orosomucoid this is easy to understand as it is another low molecular weight protein filtered through the glomeruli and reabsorbed in the tubules. Of greater interest is the tendency towards higher urinary albumin excretion among people with tubular dysfunction. None of those examined, however, with the exception of the 63 year old man discussed above, had urinary albumin concentrations exceeding the concentration of about $10 \mathrm{mg} / \mathrm{mmol}$ creatinine, which has been used as a limit for the diagnosis of glomerular proteinuria. ${ }^{1237}$

Our interpretation is that the tendency towards higher urinary concentrations of albumin among workers with tubular impairment is related to a decreased tubular reabsorption capacity rather than to an increased glomerular permeability for larger proteins as was suggested by Bernard and coworkers. ${ }^{1011}$ We believe that the increased urinary albumin excretion seen among those with tubular impairment simply constitutes further evidence of tubular damage as larger proteins, such as albumin, are also filtered through the glomerulus, although to a much lesser extent than are low molecular proteins. ${ }^{1215}$ Thus tubular impairment will also result in an increased urinary excretion of larger proteins.

On the other hand, measurements of the GFR using CrEDTA clearance showed that, on average, people with tubular damage also had a reduction in GFR ( $84 \%$ of age predicted value) and, furthermore, there was a significant correlation between tubular reabsorption loss and GFR (fig 6). In support of these findings a negative relation between tubular damage and decrease in GFR, as measured by endogenous creatinine clearance, was recently reported from environmentally exposed Japanese farmers. ${ }^{38}$

Taken together, these findings strengthen the value of measuring low molecular weight proteins, such as $\beta_{2}$-microglobulin, in urine in order to identify the early adverse effects on health caused by exposure to cadmium. If the tubular proteinuria is prevented it is also likely that glomerular effects will be avoided.

Ester Randma took care of the sampling in connection with the health examination. Help from the Roxen Health Care Unit is highly appreciated. Protein analysis was performed by Helene Saranius and cadmium in urine was measured by Anita Engqvist, Gunnel Gustaver, Siw Siljerud, and Birgit Åkerlund.
Lars Linnman assisted in compiling figures, tables, and in performing statistics.

Financial support has been obtained from the Swedish Work Environment Fund (83-0122), Folksam (a Swedish insurance company), and the company.

\section{References}

${ }^{1}$ Friberg L. Health hazards in the manufacture of alkaline accumulators with special reference to chronic cadmium poisoning. Acta Med Scand 1950;suppl 240:1-124.

${ }^{2}$ Friberg L. Cadmium and the kidney. Environ Health Perspect 1984;54:1-11.

${ }^{3}$ Bonnell JA. Emphysema and proteinuria in men casting coppercadmium alloys. $\mathrm{Br} J$ Ind $\mathrm{Med}$ 1955;12:181-97.

${ }^{4}$ Piscator M. Proteinuria in chronic cadmium poisoning. I An electrophoretic and chemical study of urinary and serum proteins from workers with chronic cadmium poisoning. Arch Environ Health 1962;4:607-21.

${ }^{5}$ Kazantzis G, Flynn FV, Spowage JS, Trott DG. Renal tubular malfunction and pulmonary emphysema in cadmium pigment workers. $Q J$ Med 1963;32:165-92.

${ }^{6}$ Piscator M. Proteinuria in chronic cadmium poisoning. III Electrophoretic and immunoelectrophoretic studies on urinary proteins from cadmium workers, with special reference to the excretion of low molecular weight proteins. Arch Environ Health 1966;12:335-44.

${ }^{7}$ Piscator M. Proteinuria in chronic cadmium poisoning. IV Gel filtration and ion-exchange chromatography of urinary proteins from cadmium workers. Arch Environ Health 1966;12:345-59.

${ }^{8}$ Lauwerys RR, Buchet J-P, Roels HA, Brouwers J, Stanescu D. Epidemiological survey of workers exposed to cadmium. Arch Environ Health 1974;28:145-8.

${ }^{9}$ Lauwerys RR, Roels HA, Buchet J-P, Bernard A, Stanescu D. Investigations on the lung and kidney function in workers exposed to cadmium. Environ Health Perspect 1979;28:137-45.

${ }^{10}$ Bernard A, Roels H, Hubermont G, Buchet JP, Masson PL, Lauwerys RR. Characterization of the proteinuria in cadmiumexposed workers. Int Arch Occup Environ Health 1976;38:19-30.

${ }^{11}$ Bernard A, Buchet JP, Roels H, Masson P, Lauwerys R. Renal excretion of proteins and enzymes in workers exposed to cadmium. Eur J Clin Invest 1979:9:11-22.

12 Peterson PA, Evrin PE, Berggaard 1. Differentiation of glomerular, tubular and normal proteinuria: determinations of urinary excretion, $\beta_{2}$-microglobulin, albumin and total protein. $J$ Clin Invest 1969;48:1189-98.

${ }^{13}$ Hansén L, Kjellström T, Vesterberg O. Evaluation of different urinary proteins excreted after occupational $\mathrm{Cd}$ exposure. Int Arch Occup Environ Health 1977;40:273-82.

${ }^{14}$ Butler EA, Flynn FV, Harris H, Robson EB. A study of urine proteins by two dimensional electrophoresis with special reference to the proteinuria of renal tubular disorders. Clin Chim Acta 1962;7:34-41.

${ }^{15}$ Maack T, Johnson V, Kan ST, Figueiredo J, Sigulem D. Renal filtration transport and metabolism of low-molecular weight proteins: a review. Kidney Int 1979;16:251-70.

${ }^{16}$ Morgan DB. Assessment of renal tubular function and damage and their clinical significance. Ann Clin Biochem 1982;19:307-13.

${ }^{17}$ Friberg L, Piscator M, Nordberg GF, Kjellström T. Cadmium in the environment. 2nd ed. Cleveland, Ohio: CRC Press, 1974.

${ }^{18}$ Axelson B. Urinary calculus in long-term exposure to cadmium. XIV International Congress on Occupational Health 1963;281:939-42.

${ }^{19}$ Adams RG, Harrison JF, Scott P. The development of cadmiuminduced proteinuria, impaired renal function and osteomalacia in alkaline battery workers. $Q J$ Med 1969;38:425-43.

${ }^{20}$ Scott R, Mills EA, Fell GS, et al. Clinical and biochemical abnor- 
malities in coppersmiths exposed to cadmium. Lancet 1976;ii:396-8.

${ }^{21}$ Scott R, Patterson PJ, Burns R, et al. Hypercalciuria related to cadmium exposure. Urology 1978;11:462-5.

${ }^{22}$ Holden H. A mortality study of workers exposed to cadmium fumes. In: Cadmium 79: edited proceedings, 2nd international cadmium conference, Cannes, 1979. London: Cadmium Association, 1980:211-5.

${ }^{23}$ Andersson K, Elinder CG, Hogstedt C, Kjellström T, Spång G. Mortality among cadmium and nickel-exposed workers in a Swedish battery factory. Toxicology and Environmental Chem. istry 1984;9:53-62.

${ }^{24}$ Hallne U, Bergström B, Hallberg B-O. Measurements of airpollutants during welding and soldering. Report. Solna: National Board of Occupational Safety and Health, 1977:300. (In Swedish.)

${ }^{25} \mathrm{Kjellström} \mathrm{T,} \mathrm{Piscator} \mathrm{M.} \mathrm{Quantitative} \mathrm{analysis} \mathrm{of} \beta_{2}$-microglobulin in urine as an indicator of renal tubular damage induced by cad mium. Uppsala: Diagnostic Communications, Pharmacia Diagnostics AB, 1977:3-21. (Phadedoc No 1.)

${ }^{26}$ Vesterberg $O$. Quantification of albumin in urine by a new method: zone immunoelectrophoresis assay (ZIA). Clin Chim Acta 1981;113:305-10.

${ }^{27}$ Method for creatinine determination by LKB 8600 reaction rate analyzer, Boehringer Mannheim GMBH. Diagnostica 1975.

${ }^{28}$ Vesterberg $\mathrm{O}$, Wrangskogh $\mathrm{K}$. Determination of cadmium in urine by graphite-furnace atomic absorption spectroscopy. Clin Chem 1978;24:681-5.

${ }^{29}$ Evrin P-E, Wibell L. The serum levels and urinary excretion of $\beta_{2}$-microglobulin in apparently healthy subjects. Scand J Clin
Lab Invest 1972;29:69-74.

${ }^{30}$ Bröchner-Mortensen J. A simple method for the determination of glomerular filtration rate. Scand $J$ Clin Lab Invest 1972;30:271-4.

${ }^{31}$ Jawaid M, Lind M, Elinder CG. Cadmium in urine-a new rapid AAS-extraction method applied on urine from smokers and non-smokers of different sex and age. Talanta 1983;30:509-13.

${ }^{32}$ Buchet JP, Roels H, Bernard A, Lauwerys R. Assessment of renal function of workers exposed to inorganic lead, cadmium or mercury vapor. J Occup Med 1980;22:741-9.

${ }^{33}$ Askergren A, Allgén L-G, Karlsson C, Lundberg I, Nyberg E. Studies on kidney function in subjects exposed to organic solvents. Acta Med Scand 1981;209:479-83.

${ }^{34}$ Kjellström T, Evrin P-E, Rahnster B. Dose-response analysis of cadmium-induced tubular proteinuria. A study of urinary $\beta_{2}$-microglobulin excretion among workers in a battery factor. Environ Res 1977;13:303-17.

${ }^{35}$ Granerus G, Aurell M. Reference valus for ${ }^{51} \mathrm{Cr}$-EDTA clearance as a measure of glomerular filtration rate. Scand J Clin Invest 1981;41:611-6.

${ }^{36}$ Ljunghall $\mathrm{S}$, Hedstrand $\mathrm{H}$. Epidemiology of renal stones in a middle-aged male population. Acta Med Scand 1975;197:439-45.

${ }^{37}$ Blainey JD, Brewer DB, Hardwicke J. Proteinuria and the nephrotic syndrome. In: Black D Sr, Jones NF, eds. Renal disease. Oxford: Blackwell Scientific Publications, 1979:383-99.

${ }^{38}$ Nogawa K. Biologic indicators of cadmium nephrotoxicity in persons with low-level cadmium exposure. Environ Health Perspect 1984;54:163-9. 